\title{
ALLUSIONS TO THE CELESTINA IN WORKS WRITTEN OR PUBLISHED IN FRANCE UP TO 1644
}

\author{
Denis Drysdall \\ University of Waikato, New Zealand
}

The first writer to name the Celestina in another work was the Savoyard lawyer Giovanni Nevizzano, in his Silva nuptialis ... (Asti: Francesco de Silva, 1518). This was reprinted in Paris by Jean Kerver in $1521 .{ }^{1}$ On fo xxvii $r_{-}-v_{-}$, against a marginal note, "Sola virginitas nequit reddi," we read:

Propterea Apuleius in magia dicebat quod quidcunque in dotem acciperis: potes cum libuerit reddere sola virginitas reddi nequit sola apud maritum ex rebus dotalibus permanet. Est verum secundum aliquos quod virgines magis appetunt coitum quam coniugatæ: quare dulcius putant quod numquam expertæ sunt. Et tamen postea comperiunt eam voluptatem esse: sicut sunt ceteræ huius mundi quæ momento vix durant: et eas pænitet sceleris comissi: et de earum digitis et aliis foedissimis spurcitiis: late Philelfus decade iiii satira ii incipiente $O$ pueri. Ideo felix tibi si illa quam credis virginem non fecerit nisi unum spurium: rosarium Busti prima parte sermone xxiiii littera n. Et nota quia ille erat ordinis minorum de observantia ad quem verisimiliter concurrebant puellæ ad confitendum. Ideo debebat scire cur ita

${ }^{1}$ There are copies of the 1518 edition in the Biblioteca reale, Turin (E 52[4]), and in the Biblioteca Apostolica Vaticana. A copy of the 1521 reprint is in the British Library, G.16433. 
diceret quia medicaminibus sciunt restringere instrumentum suum: prout de domina Caracosa quam refert Præpositinus in capitulo consultatio de frigidis et maleficiatis ${ }^{2}$ quæ ut placeret marito tantum se restrinxit quod nec ipse nec alius potuit amplius eam cognoscere: de qua arte vide in Enea muliebri capitulo ii charta $x$ et in tragicomedia Celestinæ latissime.

In the Lyon 1524 edition this paragraph was redistributed so that the allusion to the Celestina appears under the heading "Virgines quare plus appetere dicuntur coitum quam viduæ," and the paragraph begins at "Est verum secundum aliquos ..." This and all subsequent editions (of which six were printed in Lyon), considerably expanded and divided into six books, contain no less than twelve more allusions. The following is the text of Lyon, 1540:

Et dicit ipse [philosophus, ie. Aristotle] in prædicamento quod dubitare de singulis non est inutile refert ... Hadrianus VI papa noster in quodlibetis quæstione vi columna penultima \& Sempronius apud celestinam capitulo i quod sol reverberatus fortius calefacit \& clavus repercussus fortius stringit. (fo iv $r^{\circ}$ )

[In a paragraph headed "Omnis mulier mala"] Plura videre potes de istis in locis allegatis supra in primis verbis conclusionis. Et ultra ibi adducta vide late comicos et satyricos etiam præsertim. de quibus in capitulo satyra secunda distinctione Carmelitanum in bucolicis egloga iiii. Merlinum cocaium macaronices libri iiii ante finem. bibliam auream capitulo xvi de falaciis mulierum Platinam contra amores carta penultima et finali. Rosarium busti libro ii sermone xxviii ii parte litera d. Claudius super lu[cam?]. tractatu $v$ super ii caput circa principium. Et tu hispane sempronium apud celestinam capitulo i. (fo xxxiiii $v^{\circ}$ )

(fo lxiii $v^{o}$ : the passage from 1521)

Propterea plura requiriuntur ut mulier possit dici pulchra vide codrum sermone ii charta iiii. Anterota fregosii circa finem ubi ponunt etiam veram mensuram pulchritudinis aliquid Calistus in Celestina capitulo i. (fo lxxviii $v^{(1)}$

Immo quandoque adsunt mariti odientes pulchram uxorem et ardentes amore alicuius meretricis deformis: et cum illius 
deformitas eis obiicitur: respondent eam non vides oculis meis. Frater Bernard[inus], i parte rosarii sermone xxiii litera e. Lancelot in lege cum. Servus. §. scio. ff. [ie. the Digest] de lege j. sed sempronius apud celestinam dicebat in capitulo [i] cum oculis s[cilicet] speculi ignei. quod parvum facit videri magnum. (fo lxxix $v^{\circ}$ )

... facit celestina actu iiii incipiente adeso circa medium ubi de avaritia divitum actu xii post medium. (fo $\mathrm{cxi}^{\circ} \mathrm{v}^{\mathrm{O}}$ )

Licet præmittant honesta \& dulcia verba etenim non omnis qui dicit pax vobis quasi columba est audiendus ... Et celestina semper incedebat cum mantello beghinarum \& longa filzia paternostrorum: \& plebanus Arlottus in penultimo quinterno faceciarum postquam dixit a furore rusticorum: conscientia sacerdotum: disputatione medicorum: cetera notariorum / libera me domine subiicit \& ab audie[n]te duas missas omni mane / et a iurante per conscientiam meam prout semper faciebat celestina \& omnino corrumpunt bonos mores colloquia mala. (fo cxxxi ${ }^{\circ}$

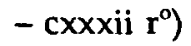

... plura tradit celestina in laudem vini. Actuum ix incipiente porta. (fo cxlvi $r^{\circ}-v^{\circ}$ )

... licet senectus multa habeat mala de quibus celestina Actu iiii incipiente adesso. (fo $\mathrm{cl} \mathrm{v}^{\circ}$ )

Et quid inde si artibus volunt suam pulchritudinem conservare postquam velati defectus quandoque producunt effectus. Baldus in repe[rtorio?] lex emilius ff. [Digest] de minor[ibus] columna $\mathrm{v}$ facit Celestina circa finem vi actus ... (fo cliii $v^{\circ}$ )

Nobilis præsumitur liberalis quare avaricia homines facit odiosos largitas claros ... Et Marcus varro inquit semel dedit qui rogatus: bis qui non rogatus. late celestina in principio secundi actus incipiente fratelli. (fo clvii $v^{\circ}$ )

Plura hicinde potes colligere in ovidio de tristibus libro iii sub rubrica ad amicum ut magnorum virorum consuetudinem fugiat celestina. Actu ix incipiente porta post medium. (fo clxix $\mathbf{r}^{\circ}$ )

Henricus Cornelius Agrippa strongly condemned the work for its potentially evil effects. His De incertitudine et vanitate oinnium Scientiarum et artium ... was written in 1526; it was first printed at Antwerp (Io. 
Grapheus) in 1530, and then in Paris (lo. Petrus) in 1531. The following is from the first edition, ch. 64 :

Superiorem tamen istis [Poetis et Rhetoribus] locum possident Historici, illi præcipue qui amatorias illas Historias contexuerunt Lancelloti, Tristamii [sic], Eurialis, Pelegrini, Calisti et similium in quibus fornicationi et adulteriis a teneris annis puellæ instituuntur et assuescunt, necque vero machina quævis ad opugnandum cum matronarum pudicitiam tum virginum ac viduarum castimoniam validior quam lectio lascivæ Historiæ, nulla tam bonæ indolis fœemina, quæ hac ipsa non corrumpatur, mirum quam putarim si aliqua reperiatur aut mulier aut puella tam exactæ castitatis sive pudicitiæ quæ ex eiusmodo lectionibus et historiis peregrina libidine non sæpe ad furorem usque accendatur. (fo $\mathrm{Zv}^{\circ}$ )

Two pages later among examples of go-betweens who used magic:

Et apud Horatium Canidia, apud Apuleium Pamphile maleficæ suos amatores astringunt, et in Calisti tragicacomodia [sic] Celestina lena Melibeam puellam accendit. Accendunt iis etiam veneficia et philtra amatoria pocula, sed admodum periculosa, ut pro amore nonnunque mortem aut aut gravem aliquem morbum inducant. (fo $\left.\mathrm{Z2} \mathrm{v}^{\mathrm{o}}-\mathrm{Z3} \mathrm{r}^{\mathrm{o}}\right)^{3}$

Agrippa was the victim of a chance irony, for the Sorbonne condemned his treatise, "publice exurendum," on the very day (2 March 1531) it passed the Celestina without comment:

"Determinatio Facultatis THEOlogl LIBELLORUM, AD EAM UT DE EIS SUUM FERRET IUDICIUM TRANSMISSORUM..."

... et de alio [libro] qui dicitur, la Celestine, qui etiam inveni dicuntur apud Ioannem de Saint Denys, nihil diximus. ${ }^{4}$

${ }^{3}$ The first of Agrippa's allusions was omitted by Henri de Mayerne Turquet when he translated the work into French (Paris: J. Durand, 1582), but the second was retained (p. 292).

4 In Duplessis d'Argentré, Collectio judiciorum de novis erroribus (Pari: A. Cailleau, 1728), II, 85. The index gives the date: "Anno 1530 [ie. 1531], die 2 Mart." 
Antoine du Saix, abbot of the order of St Anthony at Bourg-enBresse, ${ }^{5}$ in Lesperon de discipline ... (Lyon [?], S.Gryphius [?], 1532), likewise sees no harm in the work and others like it, but accords it no esteem and is more concerned to ensure the good standing of those who publish legal works:

J'estimerois que ignorants n'eussent loy Que d'imprimer le compte Meleusine, Ou Taillevent le maistre de cuisine Le grand Albert quant aux secrets des femmes, Matheolus, vray advocat des dames, Vente d'amours, la guerre des grenoilles, Les droiz nouveaulx, le livre des Quenoilles, Le Testament maistre François Villon, Jehan de Paris, Goddefroy de Billon, Artus le Preux ou Fierabras le Quin, Tous les vaillantz et Bertrand du Clecquin, La Maguelonne et Pierre de Provence, Le Peregrin pour fraische souvenance, Ou Scelestine et le Perceforest, Roland, Maugis, Dardaine la Forest, Prison d'amours, addition et glose, Finablement le Roman de la Rose, Ce sont traictez quion ne doibt estimer. Sçavantz ou non les peuvent imprimer. Mais à cella qui concerne la Loy Mettre on n'y doibt que gens de bon alloy. (fo I ii $v^{0}-$ iii $r^{0}$ )

The Toulousain rhétoriqueur poet, Gratien du Pont, is a virulent antifeminist for whom the Celestina is nothing more than amunition in the "Querelle des femmes." In his Controversses [sic] des Sexes Masculin et Femenin (Toulouse: Jacques Colomies, 1534), he names the work in a table of those "par lesquelz est confermé le dire de Lautheur" (fo CCC iiii $\mathrm{r}^{\circ}$ ). On folios cxxv $v^{\circ}-\operatorname{cxxvi} v^{\circ}$ he has a versified list, under the heading "Les autheurs qui blasment les femmes, et en quel lieu," copied name for name from Nevizzano: ${ }^{6}$

${ }^{5}$ The friend of Rabelais, who styles him "commandeur jambonnier."

${ }^{6}$ Gerard J. Brault, who edited the first French translation of 1527 (Detroit: Wayne State UP, 1963), claims that "Sempronio's antifeministic tirades provide Gratien du Pont with fuel for his contribution to the Querelle des femmes" (p. 3). But since every point which Du Pont might be taking from Sempronio's tirade 
Premierement : cez gentilz satyriques

Qui de telz dictz : sont tresfort iuridicques

Qui nommez sont : au lieu quau marge a[\$be margin is blank]

Avec merlin : qui bien croyre debvez

La bible dicte : doree en ses diffames

Dans ce beau tiltre : des fallaces des femmes

Platine aussy : et le bon obseruant

Buste nommé : iuste, droict obseruant

Claude aussy bien : au cinquiesme traicté

Pareillement : beaucoulp en a traicté

Sempronius : lespaignol aussy bien

Vous en dira : quelque chose de bien ...

Clément Marot's allusion to theologians and their preposterous disputes seems to suggest that he did not approve of the Sorbonne's decision and that his quotation of the Celestina is maliciously ironical. His "EPITRE DU COQ EN L'ANE ENVOYÉ A LYON JANET DE SANSAY EN POITOU" dates from 1535.?

Asçavoir mon si les bossus

Seront tous droicts en l'aultre monde?

Je le dy pource qu'on se fonde

Trop sus Venus et sus les vins;

Pourquoy je ne veulx qu'aux Devins

Personne sa fiance mette.

Or ça: le livre de Flammette,

Formosum pastor, Celestine,

Tout cela est bonne doctrine,

Et n'y a rien de deffendu.

Nicolas de Troyes attempted, unsuccessfully, to introduce "celestin, celestine" into French as a common noun. He adapted material from acts I, II, VII and IX of the Celestina to make one of his collection of short

(Act 1) is also a common place of antifeminist discourse at the time, it would be unwise to assume direct borrowing. Du Pont may not in fact have read all the works whose names he so obviously takes from Nevizzano.

' Ed Georges Guiffrey, Les CEuvres de ... (Paris: A. Quantin, 1881), III, 358-359, 11. 94-103. See Guiffrey's note, pp. 359-360, and the edition of C. A. Meyer (London: Athlone Press, 1962), p. 126, note 6. 
stories, the Grant parangon des nouvelles nouvelles (1537). ${ }^{8}$ I3 1, 4s the figures of Calisto and Melibea completely, and makes it clear that his interest lies chiefly in the portrayal of life in the brothel. ${ }^{9}$ Towards the end, he inserts an episode concerning an unfaithful wife, Pasquiere, whose accommodating husband is described as a "bon Celestin." That this is indeed a masculine form of the name, used as an equivalent of "entremetteur" (go-between), is confirmed by another story, very similar in content to this episode, about one Jehan Hihou, who is four times described in the same way. In two other stories, the name is used as a common noun in the feminine form, five times in a story adapted from the Quinze joies de mariage, and once in a tale of a chambermaid, Jehanne, who acts as a go-between for her mistress.

\section{[CÉLESTINE] $]^{10}$}

Ainsi m'aide Dieu, mon enfent, dit Celestine, tu fais bien, car ton mary es[t] bon celestin, et congnois bien à ceste heure que tu es large et habandonnée. (Kasprzyck, p. 296, 11. 1280-1282)

\section{[LE MARI ENTREMETTEUR]}

Et si d'aventure tu m'as trouvé avec elle devisant et esbatent sans pencer en nul mal, pences tu que je vousisse faire comme toy qui en es droit celestin? (p. 135, 11. 101-104)

${ }^{8}$ Only part of the original collection survived. It remained in manuscript until it was edited in part by Emile Mabille (Brussels, 1866-1869); this edition does not contain the tale adapted from the Quinze joies de mariage. A selection was published in a critical edition for the Société des Textes Français Modernes by Krystyna Kasprzyck (Paris: Didier, 1970), which places this and the Celestina story in an appendix, but does not contain the story of the chambermaid Jehanne.

${ }^{9}$ Three other French authors make substantial borrowings from the Celestina in this period without mentioning the name. Herberay des Essarts uses elements of two speeches of Melibea and one of Calisto, from act XIV, for the seduction scene in his Lisuart de Grace ou Sixiesme Livre d'Amadis de Gaule (Paris, 1545), a translation of Feliciano de Silva's Séptimo Libro de Amadis. Guillaume Bouchet, using the translation by Jacques de Lavardin, borrows Celestina's eulogy of wine (act IX), for the first of his Serces [Soirées] (Poitiers, 1584) entitled "Du Vin," and a speech of Areusa (act IX) for the fifth, entitled "Des nouvellement mariez et mariées." For Nicolas Baudouin, see below the note on Brantôme.

${ }^{10}$ These stories have rather long "arguments" in lieu of titles. In all cases but the last I give, in brackets, the title attributed by the modern editor. 
Tu as envoyé des presens au chanoine au nom de ta femme affin qu'il l'aymast mieux. Or congnois à ceste heure que tu en es celestin. (pp. 136-7, Il. 138-140)

Toy mesmes vent [sic] ta femme, puisque tu prens ces biens là, mais il ne s'en soucie pas car il se recompense sur elle. Regarde, homme de bien de celestin que tu congnois, quelz hostes te amena il à loger cheulx toy et les grant banquetz qui s'y faisoint! (p. 138, 1l. 194-198)

... tu l'as invité, à gouter plusieurs foys avec toy, luy disant: "Mons. venés à deux heures et nous ferons bonne chere." Il n'y failloit pas, mais toy, tu n'y venois qu'i ne fust catre heures: et n'est ce pas sine d'un bon celestin et d'un homme qui ne veulx [sic] pas garder sa femme? (p.141, 11. 258-263)

\section{[LES JOIES DU MARIAGE]}

Or i avoit il une maistresse matrosne celestine, qui a tous propos la venoit veoir pour gaingner quelque robbe, cotte ou chaperon, pour la mener en quelque voyage. Cette femme cy celestine vous avoit une audace et une preeminence de president et à tous propos elle appelloit ceste dame sa cousine et commere. (p. 304, 11. 39-45)

Alors dit la celestine: "Certes mon compere, mon amy ..." (p. 305, 1l. 64-65)

"Par ma foy, dit la celestine ..." (p. 305, 1. 75)

Lors dit la celestine: "Certes, ma cousine ..." (p. 306, l. 91)

Lors le mary tire arriere sa commere la celestine ... (p. 306, 1. 94)

[Story of the chambermaid Jehanne]

... Jehanne print ces six escus pour estre celestine de sa maistresse ... (Mabille, p. 278)

The masculine form of the term is also used once in Nicolas's table of contents, where one story is said to be by "le celestin du pont," a personage identified by Kasprzyck with archbishop Torvilliers, narrator of several other tales. ${ }^{11}$ This story, no 1 of the Cent nouvelles nouvelles, is not reproduced by either editor.

In the sixteenth story of Bonaventure des Périers's Nouvelles récréations et joyeux devis (1558) the hero has Panurge's problem: he is contemplating marriage - and cuckoldry. The reading he has undertaken by way of preparation includes the Celestina.

${ }^{11}$ Kasprzyck, p. 5, 1. 122 and p. 362. 
Il ne se soucioit pas trop d'espouser femme, craignant ce maudit et commun mal de cocuage ... Et puis il avoit reduict en memoire et par escript les ruses plus singulières que les femmes inventent pour avoir leur plaisir. Il sçavoit les allées et venues que font les vieilles par les maisons, soubz ombre de porter du fil, de la toile, des ouvrages, des petits chiens ... et avec cela il avoit leu Boccace et Celestine. Et de tout cela deliberoit de se faire sage, faisant les desseins en soy-mesme: Je feray le meilleur devoir que je pourroy, pour ne porter point les cornes. ${ }^{12}$

Nicolas Edoard, publisher of a probably pirated edition of Joachim du Bellay's Courtisane romaine (Lyon, 1558), added a footnote to line 34:

Pucelage feint. Art de Celestine.

The following are the lines in question:

Bien tost apres je vins entre les mains

De deux ou trois gentilz-hommes Romains,

Desquelz je fus aussi vierge rendue,

Comme j'avoy pour vierge esté vendue:

De main en main je fus mise en avant

A cinq ou six, vierge comme devant. (ll. 31-36) ${ }^{13}$

This is the same poem as appears under the title "La Vieille Courtizane" in the Bonfons edition (1584?) of Jacques de Lavardin's translation of the Celestina, where the above lines are on fo $\mathrm{Mm}$ ii $\mathrm{v}^{\circ}$.

The first French bibliographical work to cite the Celestina was the Bibliothèque of François Grudé de la Croix du Maine, published in 1584. The author speaks with admiration of Lavardin's Histoire de Georges Castriot surnommé Scanderbeg, but, on the subject of the Celestina, simply repeats information given by Lavardin and believes, wrongly, that his translation was the one published earlier in the century.

${ }^{12}$ Quoted from the Pléinde edition by Pierre Jourda in Conteurs français $d u$ seizième siècle (Paris: Gallimard, 1965), p. 407. In the original (p. 164 of the same anthology) the place here occupied by the names of Boccaccio and the Colestina was filled instead by those of "Matheolet," Juvenal, and the Quinze Joyes de mariage.

${ }^{13}$ Joachim du Bellay, CEurres poétiques, ed. H. Chamard (Paris: Hachette, 1923), V, 149-150. 
Il a traduit d'Italien en François la Tragicomedie de Celestine, écrite premierement en langue Espagnole, imprimée l'an 1578, chez Gilles Robinot. Elle a eté reveue par l'Auteur en la dernière Edition, car elle avoit eté imprimée plus de trente ans auparavant. ${ }^{14}$

A second Bibliothèque, by Antoine du Verdier, the translator of Pedro Mexias, appeared in the following year. This writer records one of the later editions of the first translation as anonymous, placing it in a list of "Livres d'auteurs incertains":

Celestine, Tragicomedie, laquelle traicte des deceptions des serviteurs envers leurs Maistres, \& des Maquerelles envers les Amoureux, imprimée à Paris, in- $8^{\circ}$, par Oudin Petit, 1542.

He records the title of Jacques de Lavardin's translation under that name, but refers to an edition of 1578 by Guillaume Chaudière. This edition, mentioned with various errors by other bibliographies but long unauthenticated, proves on discovery to have been a shared enterprise with Gilles Robinot. ${ }^{15}$

La Celestine, Tragicomedie, composée en reprehension des fols amoureux, lesquels vaincus de leurs desordonnés appetits, invoquent leurs amies \& en font un Dieu: aussi pour descouvrir les tromperies des Maquerelles, \& l'infidelité des mechans \& traistres serviteurs, traduite de nouveau par Jacques de Lavardin, \& imprimée à Paris, in-16 par Guillaume Chaudiere, $1578 .^{16}$

Jean Dagoneau published under the pseudonym of the seigneur de Cholières several collections of satirical, and often antifeminist "contes" and verse. The allusion in his Neuf Matinées (Paris: Jean Richer,

14 Paris: Abel l'Angelier, 1584, pp. 190-191. The fact that La Croix du Maine knows only the 1578 edition of Lavardin's Celestina tends to support the assumption that the undated edition by Nicolas Bonfons dates from 1584 at the earliest. This would also accord with Robinot's privilege, which was for six years. This Bibliothèque and that of Du Verdier were re-edited together in 1772 by Rigoley de Juvigny. In that edition, this article is in vol. I, pp. 420-422.

${ }^{15}$ A copy was found in the library of the Musée Condé, at Chantilly, XI. F. 56. See Celestinesca 5.2 (1981), 49-50. 288.

${ }^{16}$ Lyon: B. Honorat, 1585, pp. 241 and 608. In the 1772 edition, II, 424 and IV, 
1585) involves a quite unjustified accusation, but typifies the nature of the Celestina's reputation at this time in France.

Il y en a dix mille et plus de cent fois autant qui ou par drogues et illegitimes receptes font tarir, perdre et enaigrir la presure de leur formage, ou crainte de pis et pour iouèr au plus seur joüent à mets couvert. Ie m'en rapporte aux godemichi de velours et d'yvoire qui sont enfournez en la grotesque. Mais en toutes ces singeries et marmotteries de la Celestine, il n'y a pas la centiesme partie du plaisir qu'ont celles qui supportent le faict de nos chappons. ${ }^{17}$

Marguerite de Valois was a very different sort of writer from a very different milieu, but she has a not dissimilar idea of the Celestina as a manual of seduction. The following passage from her memoires was written about 1587 when Le Guast, a favourite of Henri III, was conducting an intrigue intended to create a division between Marguerite and her husband, then Henri of Navarre, and between the latter and her brother, the duc d'Alençon.

Cela passé, après avoir passé quelque temps à Lyon, nous allasmes en Avignon. Le Guast n'osant plus inventer de telles impostures, et voyant que je ne luy donnois aucune prise en mes actions pour, par la jalousie, me mettre mal avec le Roy mon mary, et esbranler l'amitié de mon frère et luy, il se servit d'une autre voye, qui estoit de Madame de Sauve, la gaignant tellement qu'elle se gouvernoit du tout pour luy, et usant de ses instructions non moins pernicieuses que celles de la Celestine, en peu de temps elle rendit l'amour de mon frère et du Roy mon mari, paravant tiède et lente comme celle des personnes jeunes, en une telle extremité (oublians toute ambition, tout devoir, et tout dessin) qu'ils n'avoient plus autre chose en l'esprit que la recherche de cette femme. ${ }^{18}$

${ }^{17}$ In the fourth Matinée, entitled "Des Chastrez," p. 124. Cholières may have been following Nevizzano in making Celestina responsible for this particular practice.

${ }^{18}$ Marguerite de Valois, Mémoires et Lettres de ..., ed. F. Guessard (Paris: Renouard, 1842), pp. 51-52. Guessard dates the journey to Avignon on 16 November 1574. The lies referred to are described on pp. 44-47. 
Pierre de Bourdeilles, sieur de Brantôme, devoted a "Discours" of his Dames illustres to Marguerite, who had in turn addressed her Mémoires to him. They shared an acquaintance with the Celestina; perhaps, being one of the most notable hispanophiles of his time, he had introduced it to her. Strangely, there is no reference to or borrowing from the work in his Dames galantes, whose scandalous anecdotes seem to offer the opportunity on every page. It is in his Rodomontades et gentilles rencontres espagnoles, also dedicated to Marguerite, that we find the title.

Une Dame, demandant un jour le Livre de la Celestine à un cavalier, il luy respondit, en luy donnant bonne: Per Dios, Segnora [sic], que me espanto de Vuestra Merced! Teniendo en casa el original, pedir el traslado! Parbleu vous m'étonnez, Madame! Ayant chez vous l'original, me demander la copie! ${ }^{19}$

Brantôme adds with evident enjoyment: "Bon, celuy-là!"

Florent Chrestien, who had provided a liminary elegy in eighteen quatrains for Lavardin's translation (1578), also spoke of the Celestina in a sonnet written for the second edition (1594) of Lavardin's history of the Turkish wars, the Histoire de Georges Castriot surnommé Scanderbeg. The four lines devoted to the "triste Comedie" reflect the view, which Chrestien shared with Lavardin, that the work was a fundamentally sound morality.

Tu escriuois la triste Comedie

De Celestine, et des ieunes esprits,

Qui en l'amour furent si mal appris

${ }^{19}$ Brantôme died in 1614, but his works remained in manuscript until long after. The Rodomontades appeared in the first edition of his complete works (The Hague, 1740), where the quiotations are in Spanish only. The London edition of 1779, quoted here (XIII, 210), gives a French translation. Several critics have seen similarities between some of Brantome's boasts and those of Centurio, but it must be said that the textual resemblances are slight and that he seems to have acquired all of them through intermediaries. On the other hand, a second such collection, the Rodomontades espagnoles of Nicolas Baudouin (Paris: P. Chevalier, 1607), a bilingual work intended for those who wished to learn Spanish, includes seven items borrowed directly from a Spanish Celestina. One of these, adapted from a speech of Centurio (act XVIII), may have come to him via the comedy Angelica, by Fabritio de Fornaris, a member of the Nenpolitan troup, the Confidenti. The play, an adaptation of della Porta's Olinupia, in Italian with the role of the captain in Spanish, was performed in Paris in 1585, published in the same year by Abel l'Angelier, and in a French translation by the same in 1599. 
Que la mort seule osta leur maladie. ${ }^{20}$

The satirical Confession catholique du sieur de Sancy by the protestant Agrippa d'Aubigné was published, without place or date, probably in 1600. In Book I, chapter 6 there is a tale about false miracles. Mme de la Chastre, wife of the governor of the Berry, murders a go-between, la Barthelemie, and conspires with Mme Avoye de Saint Laurent des eaux. The two assume disguises before going to confession:

La Maistresse se nomma Mademoiselle de Sainct Laurens, la Sousdame [Mme de la Chastre] prit le nom de Celestine. Arrivees aux Ardilliers, le Curé du lieu oüit sa confession du meurtre avec sanglots et soupirs; premierement de la part du Curé, et puis de Celestine; si fut d'avis le Père Confesseur que nostre Dame prist plustost la peine de reparer ce malheur par une resurrection que par une intercession: dont avint que la pauvre alcaüete [la Barthelemie], qu'on pensoit avoir non enterree, mais enmerdee dans un retrait, se trouva resuscitee par le merite du Curé. Ce fut une belle vision, quand aprés la neufvaine, Madame Celestine estant prosternee en terre devant l'autel, sa Maistresse la Damoyselle de Sainct Laurens tenant la queuè du Curé, pour monstrer l'hostie (car il n'y vouloit pas plus de tesmoins) sortit la grosse Barthelemie derriere l'autel ...

The "alcaüete" is naked, so:

Madame de la Chastre et Madame Avoye lui partagerent leurs vestements: Mademoiselle de Sainct Laurens lui donna son cotillon, Celestine sa cappe, et l'amenerent (crians miracle) au logis du Curé ...

The story ends:

Ils disent plus, que le Curé des Ardilliers fut payee en chair, que la Barthelemie avoit fait la neufvaine avec lui, qu'il trouva Mademoyselle de Sainct Laurent et la Celestine si vieilles et si maigres, qu'il n'en voulut qu'une fois.

${ }^{20}$ Paris: G. Chaudière, 1594 . The first edition (ibid., 1576) does not contain the sonnet. 
A note by the modern editors says: "La célèbre pièce espagnole de Fernando de Rojas avait été traduite en vers [sic!] français au XVIe siècle, et Célestine finit par désigner la maquerelle par excellence." ${ }^{21}$

Charles Timoléon de Beauxoncles, sieur de Sigogne, is one of only two, among the writers of satirical verse, to name Celestina as a prototype of the go-between. These references do suggest that the name is well known; but the study of character traits and activities, all of which may come from classical and medieval traditions, has never proved conclusively a direct influence of the Spanish work. Even in the case of Sigogne's Perrette there is much that distinguishes the two figures, although she is said, in the second of these two poems, to practice the art of restoring virginities.

Dialogue de PeRretTe parlant à la divine MACETTE ${ }^{22}$ (1614) Je suis d'amour la divine, Qui les arts de Celestine Amplifie tous les jours.

Stances SATYRIQUes CONTRE L'Ollivastre PERRETTE (1617)

Monstre de la cité qui contient presque un monde, Urgande inimitable en magie profonde,

De ta lubricité passant Flore et Laïs,

Dauphine du Maroc, Celestine nouvelle, A fin que nous sauvions au moins une pucelle, Va-t'en viste à la Chine et quitte le païs. ${ }^{23}$

${ }^{21}$ In CEuvres d'Agrippa d'Aubigné, ed. Henri Weber, Jacques Bailbé, and Marguerite Soulié (Paris: Gallimard [Pléiade], 1969), Pp. 602-603 and p. 1299, note 7. The editors refer (note 4), for the reputation of Mme de la Chastre, to the Bibliothèque de Montpensier, a satirical "bibliothèque imaginaire," where she is credited with a "Rhétorique des maquerelles." This work also contains a possible reference to the Celestina as follows: "Invention très subtile de Mme de Brissac pour recouvrer les cornes perdues, avec l'augmentation du sieur de Lavardin." See G. Brunet, "Essai sur les Bibliothèques Imaginaires," in the Supplément au Dictionnaire des Ouvrages anonymes (Paris: Maisonneuve et Larose, 1964), Pp. iv-v.

22 Macette is a name used by several satirists, but since Sigogne died in 1611 and Mathurin Régnier's Macette appeared in 1612, it is unlikely that this is an allusion to the most notorious of the French literary "maquerelles" of the period.

23 Sigogne, CEuvres satiriques ... ed. F. Fleuret and L. Perceau (Paris: Bibliotheque des Curieux, 1920), pp. 92 and 145. In the second poem, p. 136 we read: 
The stanzas, "DE LOUYSON," by the obscure Dauphinois poet Pierre Faucherand de Montgaillard, were first published, posthumously, in 1606. They subsequently appeared in Le Cabinet satirique in 1615.

Louyson dedans Saint Germain, Va pratiquant de main en main, Et, comme une autre Celestine, La proye ne luy peut faillir:

Elle fait la rose cueillir

Sans piquer les doits à l'espine. ${ }^{24}$

César Oudin was the royal interpreter and a teacher of Spanish. The eighth of his bilingual Diálogos muy apazilles ... Dialogues fort plaisans ..., the only one by Oudin himself, ${ }^{25}$ mentions Celestina in a way that suggests a legend had grown up that made her a historical figure.

PHILOXENA Vistes-vous là [in Salamanca] la maison de Celestine?

POLIGlote Monsieur, on me dict le lieu où elle estoit, mais ie ne fus pas si curieux que de l'aller veoir, et aussi parce qu'il me semble que c'est une fiction.

Un contrôleur d'abits, en soixante mesnages,

N'en a tant rhabillez que toy de pucellages,

Rendant mille maris abusez et cocus!

"Dauphine du Maroc" is not glossed by the modern editors, but may be explained in part as a pun based on the old slang use of "dauphin" (dos fin, dos vert) as an equivalent of "maquereau" (mackerel, and pimp). The feminine "maquerelle" was common slang for "entremetteuse," but "dauphine" is not attested elsewhere.

${ }^{24}$ Le Cabinet satirique, ed. F. Fleuret and L. Perceau (Paris: J. Fort, 1924), I, 37.

${ }^{25}$ The first seven were copied from John Minsheu's Pleasant and Delightfull Dialogues in Spanish and English (London, R. Bollifant, 1599) and published by Oudin in French and Spanish in Paris in 1608 (Marc Orry) and Brussels in 1611 (R. Velpius). Juan de Luna published other editions with five extra dialogues in 1619 and 1621, but the Paris edition of 1622 (P. Billaine) is the first to contain this dialogue. Oudin died in 1625 , but there are several later editions including one of 1650 by his son Antoine, who confirms that Poliglote represents his father. 
Nicolas Lancelot's short story, "La Dévote Hypocrite," is a translation of Lugo y Dávila's "Las dos hermanas," but is much expanded. Among the additions we find that the go-between Lamie had: plus étudié dans les livres de Célestine que dans les œuvres de Grenade. ${ }^{26}$

The name and character of Lamie, the "dévote hypocrite," like many of the preceding cases, raise problems concerning the nature of the hypocrisy and of the witchcraft which are attributed to Celestina in France at this time.

A short story, dating from 1644 and entitled "D'un ieune homme qui fut attrapé par la fille de son hoste," by Antoine le Métel, sieur d'Ouville, contains the last reference to the Celestina in a French literary work of this period. The old bawd is named, as in many earlier cases, as a prototype of the intriguing go-between. But the comparison, even more than most of these, seems forced or perhaps almost a cliché, for the young woman is portrayed very sketchily and her activities amount to very little.

... il trouvait en Brigide un vray portrait de Celestine, quoy que plus ieune qu'elle ...27

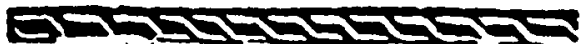

${ }^{26}$ Paris: P. Billaine, 1628, p. 219. The Spanish original contains no reference to Celestina. The name does appear in French translations of certain Latin and Spanish works: Guevara, Aviso de privados ..., trans J. de Rochemore, Le Favori de court (Antwerp: Plantin, 1577), fo $18 \mathrm{v}^{\circ}$; Vives, De institutione founina Christianx, trans. anon. Les trois livres de ... pour l'instruxion de la femme Chréticnue, (Paris: Linocier, 1587), fo $30 \mathrm{v}^{\circ}$ (not found in the earlier translation by Pierre de Changy); Juan de Luna, Segunda parte de la vida del Lazarillo de Tormes, trans. anon. La vie de Lazarille de Tormes (Paris: P. Baudouin, 1660), p. 533; Gracińn, El Criticón, trans G. de Monaury, L'Homme détrompé (La Haye: J. van Ellinckhuysen, 1708), II, 128. Other allusions in Spanish literature - Guevara, Reloj de príncipes, Cervantes, Don Quijote, Salas Barbadillo, El sagaz Estacio - do not appear in the early French translations.

27 Contes aux heures perdues (Paris: Toussaint Quinet, 1644), IV, 228. By coincidence, the 1644 reprint of the third French translation, a bilingual text first published in Rouen and Pamplona: H. Osmont, 1633, was also the last edition of the work to appear before 1822 . 